\title{
PROTEIN-POLYSACCHARIDE INTERACTIONS IN DAIRY PRODUCTION
}

\author{
Igor T. Smykov \\ All-Russian Scientific Research Institute of Butter- and Cheesemaking - \\ Branch of V. M. Gorbatov Federal Research Center for Food Systems of RAS, Uglich, Yaroslavl Region, Russia
}

\author{
KEY WORDS: \\ milk proteins, polysaccharides, \\ biocomposites, dairy \\ products, functional foods, \\ nanostructure
}

\begin{abstract}
The review article examines the main global trends in the development of scientific research in the field of increasing the efficiency of dairy products production using polysaccharides of various origins and purposes. It has been shown that non-traditional polysaccharides of plant origin are increasingly involved in industrial production, including polysaccharides of aquatic organisms, which have both enhanced technological properties - emulsifying, gel-forming, texturizing, etc., and innovative nutraceutical properties that make it possible to create food products with new properties and attractive to consumers. It is noted that the nature of proteinpolysaccharide interactions, depending on the types of proteins and polysaccharides used in various combinations and conditions of their interactions, can be completely different, which directly affects the organoleptic properties of the finished product. Modern research confirms that the properties of a food product are largely laid down at the molecular - nanoscale, and the development of research on protein-polysaccharide interactions, with the aim of their practical use in the production of dairy products, should be aimed at finding basic patterns in these interactions.
\end{abstract}

FUNDING: The article was published as part of the research topic No. 0585-2019-0010 of the state assignment of the V. M. Gorbatov Federal Research Center for Food Systems of RAS

\section{Introduction}

Dairy products have been in continued demand from the population throughout the history of humanity. This is due both to the unique properties of milk, inherent in nature, and to the possibility of producing from it a variety of products that have a high storage capacity and attractive taste. Numerous studies confirm the role of dairy products as an important component of a healthy diet. Modern trends in the development and production of new dairy products are aimed at increasing their functionality, reducing the loss of raw materials and meeting the needs of various segments of the population. One of the promising directions in the development of new dairy products is the use of polysaccharides of various origins in them. For example, in the review [1] devoted to the analysis of modern trends in the use of food polysaccharides, mainly of plant origin, it was shown that there are promising results for their use as food additives to control the organoleptic properties of products, as well as sources of biologically active compounds for functional dairy products. This approach not only allows taking a step forward in reducing waste in the food chain, but also offers new ways to diversify dairy production, creating the opportunity to occupy a market niche based on new functional products.

Milk is the best known and most widespread natural hydrocolloid. However, there is a wide variety of other hydrocolloids, which are hydrophilic biopolymers of plants, animals, and microorganisms that can be used in the food industry. Review work [2] is devoted to the analysis of the use of known and potential natural hydrocolloids based on proteins and polysaccharides in the food industry. This review reflects the most recent concepts for the use of hydrocolloids to meet the requirements of consumers and the food industry.

Hydrogels formed from hydrocolloids are three-dimensional networks of hydrophilic biopolymers that can absorb significant amounts of water without dissolving or losing their structural integrity. The use of natural hydrogels from food biopolymers has become widespread in recent decades. In work [3], the basic principles of designing food gels are considered, aimed at changing the rheological and tribological properties of food products, modifying them while maintaining sensory perception and targeted delivery of drugs and biologically active substances into the gastrointestinal tract.

Hydrogels can be formed from hydrocolloids of protein and polysaccharide origin, as well as their composites. Protein-polysaccharide composites, as is known [4], have a wide range of applications in various areas of food production. These composites can have various physical forms, such as gels, films, fibers and individual particles, depending on their components and the particular application. Subsequent processing and use of these composites contribute to a targeted and beneficial change in their structure and properties.

Thus, the use of protein-polysaccharide compositions provides many opportunities for improving organoleptic properties, biological functions, and technological processes for the production of dairy products. The study of protein-polysaccharide interactions opens up opportunities for the development of new ingredients and biopolymer complexes with application in various areas of the food industry.

The purpose of this work is to give an idea of the elements of protein-polysaccharide compositions, how they are formed and how they are used in modern dairy production.

\section{Main part}

\subsection{Casein is the main protein in milk}

Milk proteins are the basis for the production of most dairy products. First of all, this concerns casein, which is the main protein of milk and is represented by fractions of $\alpha-, \beta$ - and $\kappa$-caseins. Casein molecules do not have a definite quaternary structure and therefore belong to the group of metamorphic proteins. The property of caseins to change their quaternary structure under the influence of external factors is decisive in the milk processing. In milk, casein is in the form of spherical micelles with a diameter of 50 to 300 nanometers (Figure 1, 
hereinafter, the author's illustrations), which include all casein fractions, and the fractional composition of micelles is different depending on their size [5].

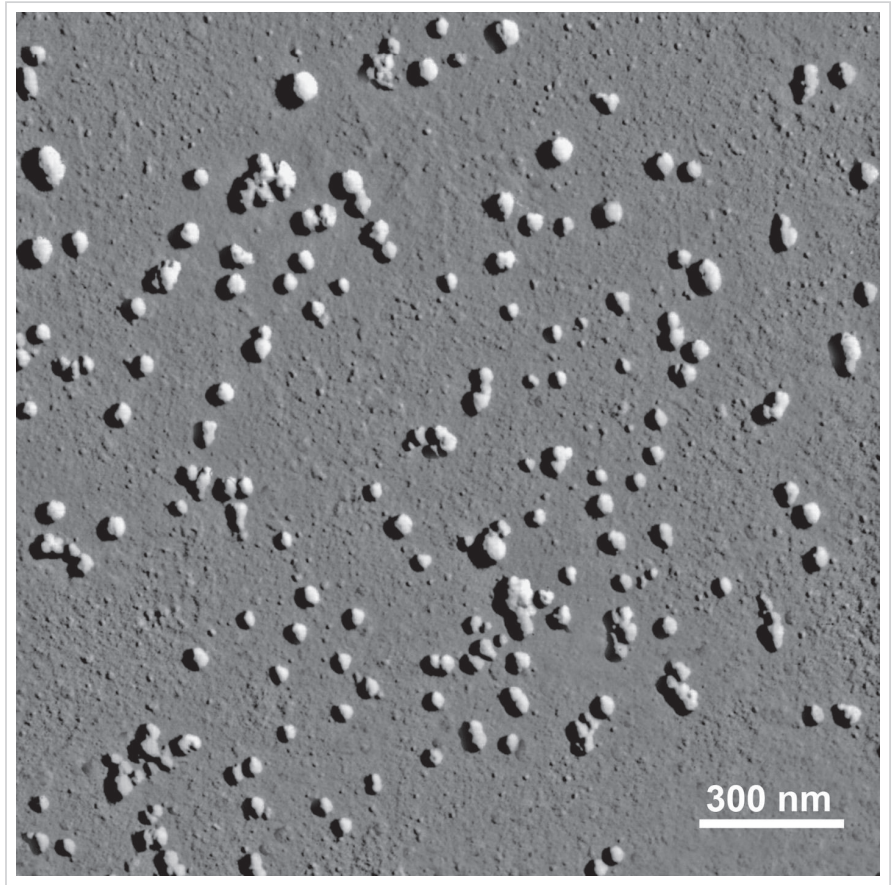

Figure 1. Casein micelles in milk

The composition of a micelle can include from several hundred to tens of thousands of molecules of various caseins, and the $\kappa$-casein molecules are predominantly located on the surface of the micelle. A distinctive feature of $\kappa$-casein is the presence of a terminal hydrophilic glycomacropeptide with a diameter of 2 and a length of about 10 nanometers [6]. The aggregate of glycomacropeptides on the surface of the micelle forms a hydrophilic «hairy» layer, which determines the hydrophilicity of the micelle and the thermodynamic stability of milk as a whole. At the same time, casein micelle has a loose internal structure containing up to $70 \%$ water, i. e. each casein micelle in milk is a stable gel particle capable of subsequent deployment under certain external influences. In addition, a hydrophilic hairy layer covers the surface of a micelle by $90-95 \%$, which, in some cases, allows micelles to carry out hydrophobic interactions [7]. This structure of micelles predetermines their interaction with the environment and determines the possibility of implementing certain technological methods in the production of dairy products.

Most of these technological methods are based on destabilization of casein micelles, which ensures the deployment of casein molecules, their activation and removal of water from micelles.

\subsection{Whey proteins}

Whey proteins are a group of different globular proteins that differ from each other in structure and properties, and, despite their small amount, are the physiologically most valuable components of milk. Whey proteins, primarily, include $\beta$-lactoglobulin (55-60\% of all whey proteins) and $\alpha$-lactalbumin (20-25\%); their molecules usually form dimers, tetramers and octamers in milk. The rest of the serum proteins are serum albumin, immunoglobulins, lactoferrin and other minor proteins [8]. $\beta$-lactoglobulin and $\alpha$-lactalbumin are of the greatest importance in the technological processes of the production of dairy products. For example, high temperatures denature whey proteins, which releases the hydrophobic regions of the mole- cules and triggers hydrophobic interactions with other proteins and, in some cases, the formation of protein gel. These proteins largely affect the organoleptic properties of the finished product by binding to caseins and other components or forming their own macrostructures (Figure 2).

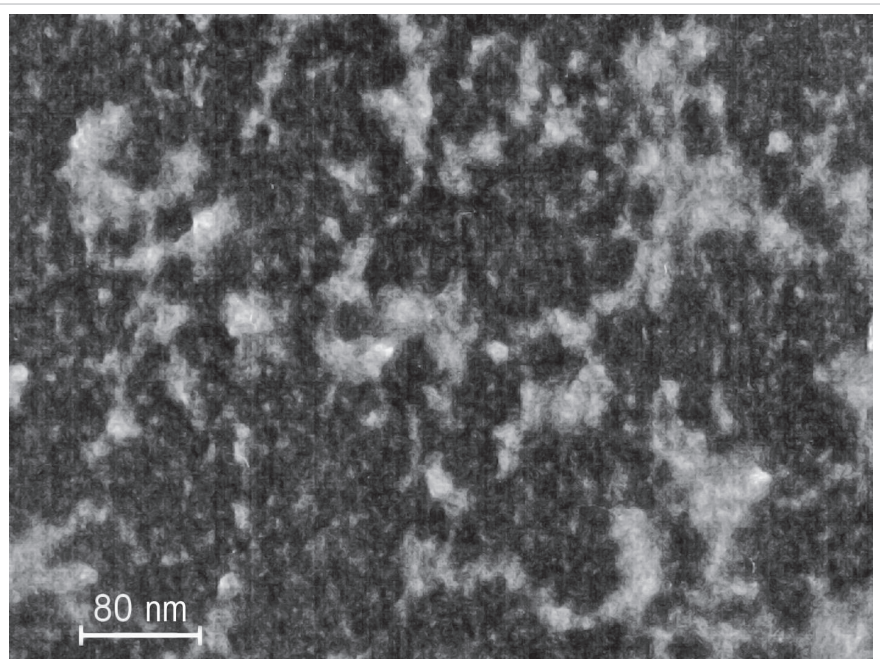

Figure 2. Nanoparticles of $\alpha$-lactalbumin

Various types of whey proteins, as well as products from them, such as whey protein isolate and whey protein concentrate, are widely used in various areas of food technology, including stabilization of foam and fat emulsions, gel formation, etc. Each specific application of whey proteins may require modification of their functional properties. For example, using enzymatic hydrolysis, thermally induced polymerization, highpressure treatment or chemical functionalization [9].

\subsection{Vegetable proteins}

Vegetable proteins are increasingly used in the production of dairy products. Since the range of vegetable proteins is very wide and their properties are very diverse, they are used to achieve different goals. There are several types of classification of vegetable proteins by their properties and fields of application (by origin, by solubility, by amino acid composition by structure, etc.) [10]. In nature, vegetable proteins mainly exist in a bound form, and therefore, for use in dairy products, it is necessary to first extract them from vegetable raw materials, purify and grind them. Depending on the results obtained of extraction, vegetable proteins can be added to dairy products to achieve various goals - structuring, enrichment, prevention, etc., attractive to potential consumers [11]. At the same time, vegetable proteins cannot completely replace milk proteins, neither in terms of amino acid composition, nor in terms of processing, nor in terms of organoleptic properties.

There are many attempts to create a milk-like food product. These milk drinks are obtained using vegetable proteins and various technological operations so that their components have dimensions close to those of natural milk components. However, this is difficult to achieve and, as a rule, electron microscopy can reveal the differences. As an example, Figure 3 shows an electron microscopic photograph of the dispersed phase of soy «milk». Comparing this photograph with Figure 1 makes it easy to notice significant differences in the structure of dispersed phases and to recognize such a structure in any way corresponding to the structure of natural milk is hardly possible. However, this and similar dairy drinks generally do not carry potential health risks and can be sought after by the consumer. However, there is a potential risk of the possibility of adulteration of a natural product. 


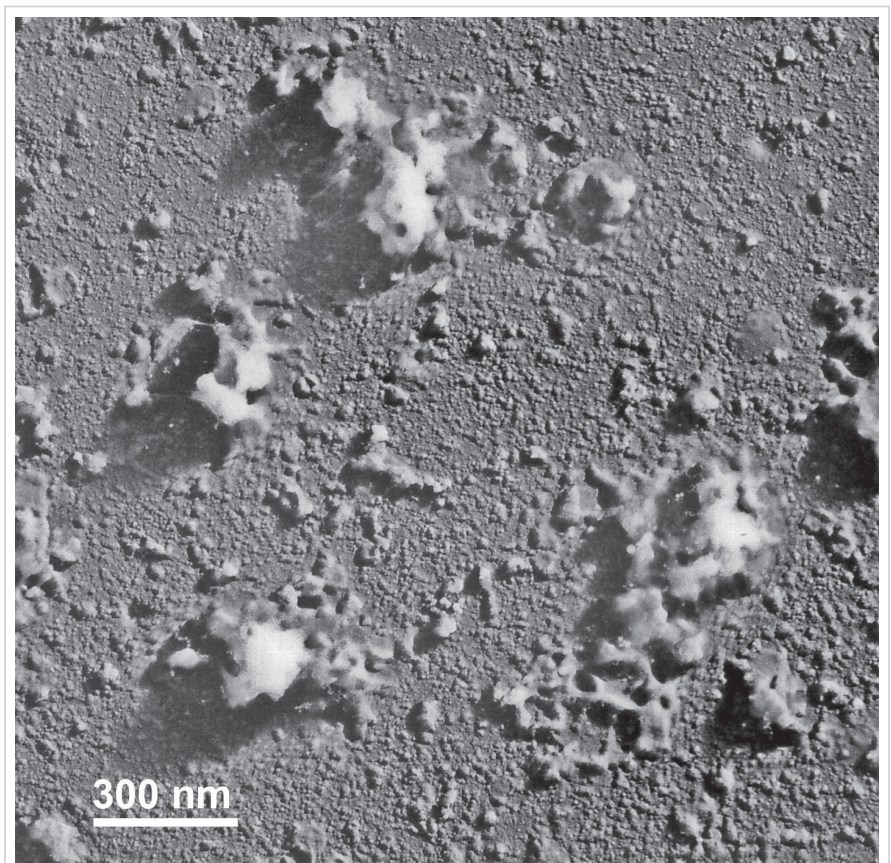

Figure 3. Particles of vegetable protein in a soy drink

\subsection{Polysaccharides}

Among natural biopolymers, polysaccharides are ideal candidates for widespread use in the food industry. They are nontoxic, biocompatible, biodegradable, hydrophilic, and have high biomimetic and physicochemical properties. Polysaccharides quantitatively represent the most important group of nutrients in food. For these reasons, in recent years, more and more attention has been paid to the non-traditional use of polysaccharides in the production of dairy products.

Polysaccharides are macromolecules of monosaccharides linked by glycosidic bonds. There are a huge number of polysaccharides with different composition and structure, with different physicochemical properties and specific functional use. All polysaccharides can be classified into groups depending on their origin: natural, semi-synthetic, synthetic [12].

Natural polysaccharides are biopolymers (Figure 4) of plant, animal, and microbial origin, for example, starch, chitin, pectin, xanthan, cellulose, etc.

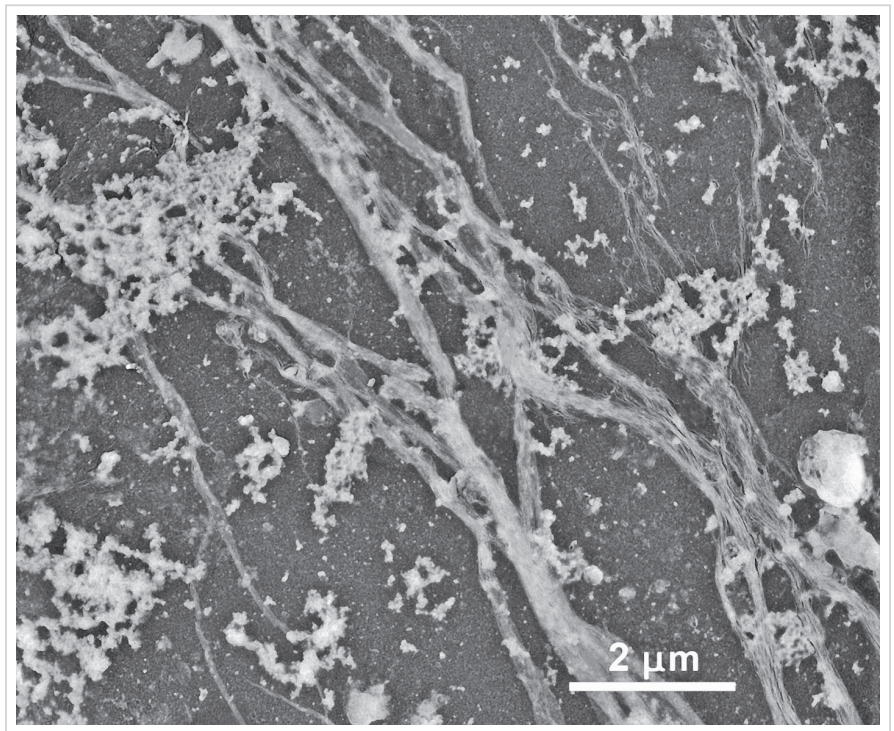

Figure 4. Polysaccharide fiber in a dairy product

Semi-synthetic polysaccharides are synthesized by modifying natural polysaccharides [13]. Starch and cellulose derivatives such as carboxymethyl cellulose and phosphorylated starch are examples of semi-synthetic polysaccharides. Semi-synthetic polysaccharides have enhanced specific properties, for example, emulsifying, non-toxic and less susceptible to microbiological deterioration.

Synthetic polysaccharides are completely produced by the chemical industry, starting from the basic components obtained during the processing of natural hydrocarbons - oil, gas. The result of the synthesis of these polysaccharides is a product with structure and properties corresponding to natural polysaccharides. Synthetic polymerization has made it possible to create analogues of natural polysaccharides such as cellulose, xylan, chitin, hyaluronan, and chondroitin, as well as unnatural polysaccharides such as a cellulose-chitin hybrid, a hyaluronanchondroitin hybrid, and others [14]. Synthetic polysaccharides have very high rates of specific properties, do not support the development of microorganisms and can be very effective for the food industry, but their possible toxicity has not yet been fully studied, and the cost remains exorbitant.

In modern conditions, the use of natural polysaccharides in the food industry, in comparison with synthetic and semi-synthetic, is preferable due to the following advantages: economy; availability; biodegradability; biocompatibility; the ability to physical and chemical modifications; non-toxicity; environmental friendliness; public acceptance. On the other hand, the growing demand for processed foods and the increasing public awareness of the importance of fiber in food has increased the consumption of foods high in polysaccharides. However, natural polysaccharides also have a number of disadvantages associated with low efficiency (compared to semi-synthetic or synthetic) and sensitivity to microorganisms. With all these advantages and disadvantages, natural polysaccharides are gradually being replaced, and further will be replaced by semi-synthetic and synthetic ones.

According to the classification based on their chemical structure, the following main structural groups of food polysaccharides are distinguished [15]: galactomannans (guar gum, tara gum), glucans (starch, curdlan), fructans (inulin, levan), xylan, ramnan, glucomannans (alginate, konjac), arabinoxylan (flaxseed gum), galactans (agar, carrageenan), arabinogalactan (gum arabic), galacturonans (pectin), glycano-rhamnogalacturonan, glycano-glycosaminoglycans, glucosamine polymers (chitin, chitosan).

The demand and supply for environmentally friendly food ingredients with natural technological (structuring, texturizing, stabilizing) and functional potentials is constantly growing. Plant seed mucilage, which is a polysaccharide hydrocolloid with a certain physicochemical and structural conformational diversity, provides a wide range of technological and functional aspects. The review [16] examines recent advances in the extraction of mucilage from plant seeds, their characteristics, and their use as alternative hydrocolloids for use in the food industry. It has been shown that food intake with mucilage from plant seeds through the oro-gastrointestinal pathway provides modulation of postprandial glycemic and insulinic responses, counteraction of hyperlipidemia, increased satiety, and regulation of the intestinal microbiota function. In addition to their important physiological role, plant seed mucilage has interesting technological, dietary, and functional properties comparable to common commercial polysaccharide hydrocolloids. Their physicochemical and structural diversification correlates with their technofunctionality, for example, gel formation, texturing, interfacial adsorption capacity, etc.

Microbial polysaccharides are released into the environment by numerous types of microorganisms in the course of their vital activity, and therefore they are collectively called exopolysac- 
charides. Due to their unique structure and physical properties, exopolysaccharides are widely used as emulsifiers, stabilizers, thickeners, texturizers, film formers and gelling agents. The most commonly used exopolysaccharides are xanthan gum, gellan gum, dextran, and pullulan [17].

Exopolysaccharides produced by lactic acid bacteria are used as natural stabilizers in fermented milk products. Figure 5 shows a photograph illustrating the interaction of thermophilic streptococci with casein micelles in yogurt and their release of exopolysaccharide (light clouds around bacteria). The ability of exopolysaccharides to regulate viscosity largely depends not only on their concentration, but also on their structure and ability to interact with other dairy compounds. The aim of the study [18] was to compare the effect of exopolysaccharides secreted by different strains of Streptococcus thermophilus on the formation of milk gel and rheological / physical properties (density, apparent viscosity, elastic modulus, syneresis) of the finished product. This work showed that gel formation and rheological / physical properties of fermented milk products are determined by the structural characteristics of exopolysaccharides, especially the magnitude of its negative charge, structural flexibility, degree of branching and molecular weight.

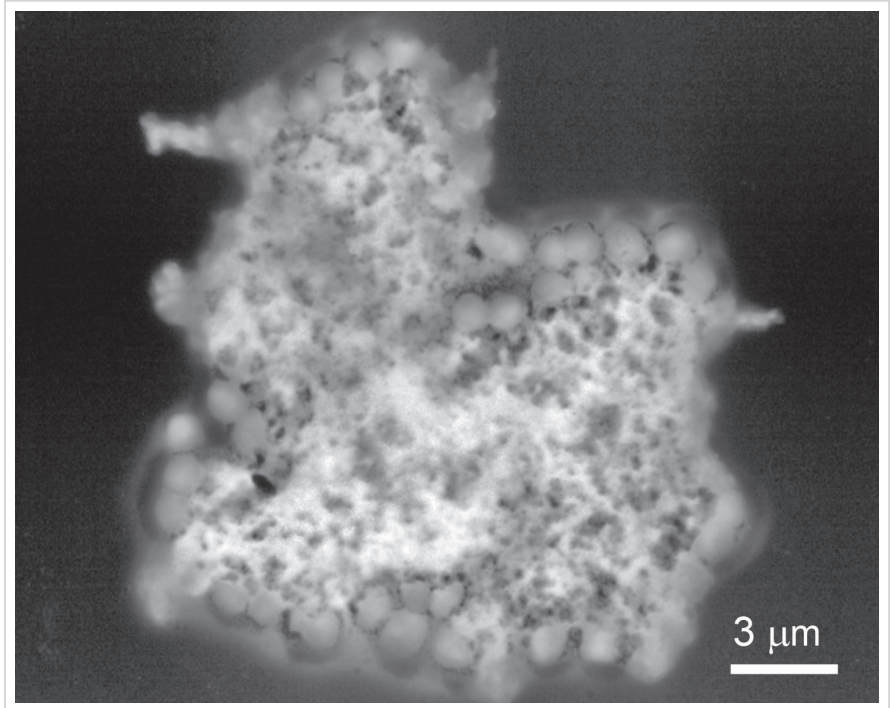

Figure 5. Exopolysaccharide Streptococcus thermophilus during milk gel formation

According to the main purpose of use, polysaccharides can be conditionally classified $[19,20,21]$ into the following groups:

$\square$ Stabilizers that maintain a uniform dispersion of two or more immiscible components in a product;

$\square$ Thickeners that increase the texture of the product;

$\square$ Emulsifiers that ensure the stability of dispersed systems with different phases such as oil/water or water/oil;

$\square$ Gelling agents that cross-link the components of the original dispersed food systems into a single structure with high water retention;

$\square$ Texturators that provide solid food products with a given texture;

$\square$ Sensitizers that improve the organoleptic properties of products;

$\square$ Functional polysaccharides, which serve as biologically active food additives to improve the condition of the human body;

$\square$ Technological polysaccharides serving to improve the efficiency of food production.

However, some polysaccharides can simultaneously perform different functions or perform different functions under different conditions of use.

\subsection{Protein-polysaccharide interactions}

Proteins and polysaccharides are found in many complex multiphase food systems. Considering the fact that in the production of dairy products together with milk proteins, vegetable proteins can be used, the number of varieties of which is quite large, as well as various polysaccharides, the number of which is even greater, the number of paired, triple and more combinations of them is simply immeasurable. Despite the obvious difficulty of describing protein-polysaccharide interactions in such food systems, leading scientists in many countries are actively involved in this problem. Thus, work [22] provides an overview of the types and nature of interactions that can occur between milk proteins and polysaccharide molecules. The extensive research carried out over the past decades describing various proteinpolysaccharide interactions and their effect on the structure and functionality of products is discussed.

The review [23] reports on some of the latest advances in this field, demonstrates interesting physicochemical properties of protein-polysaccharide conjugates as stabilizers and emulsifiers, as well as texture modifiers in food products. It also provides an overview of possible interactions between protein and polysaccharide, from the Maillard reaction to enzymatic crosslinking passing through coacervates.

Interactions of casein with various polysaccharides are considered in detail in the review work [24]. It is noted that, in general, these interactions can be associative or segregating. There are two main types of interaction between polysaccharides and proteins: strong association - irreversible binding of proteins with polysaccharides or strong electrostatic complexes; weak association - potentially reversible binding involving non-ionic and weak electrostatic complexes. Electrostatic interactions of proteins with charged sites of polysaccharides play a dominant role. Strongly interacting electrostatic complexes usually form between positively charged proteins and anionic polysaccharides. Weak reversible complexes can form between anionic polysaccharides and proteins that carry almost zero total charge or total negative charge. The distribution and type of charges on the surface of casein micelles create a repulsive barrier that contributes to the stability of the micelles in suspension. This means that if the repulsive and steric stabilizer layer is damaged or destroyed, van der Waals interactions appear and primary aggregation of casein micelles occurs. The polysaccharide macromolecules adsorbed in this process stabilize the dispersed system through steric and electrostatic interactions. The photograph in Figure 6 illustrates the nanostructure of casein-polysaccharide gel.

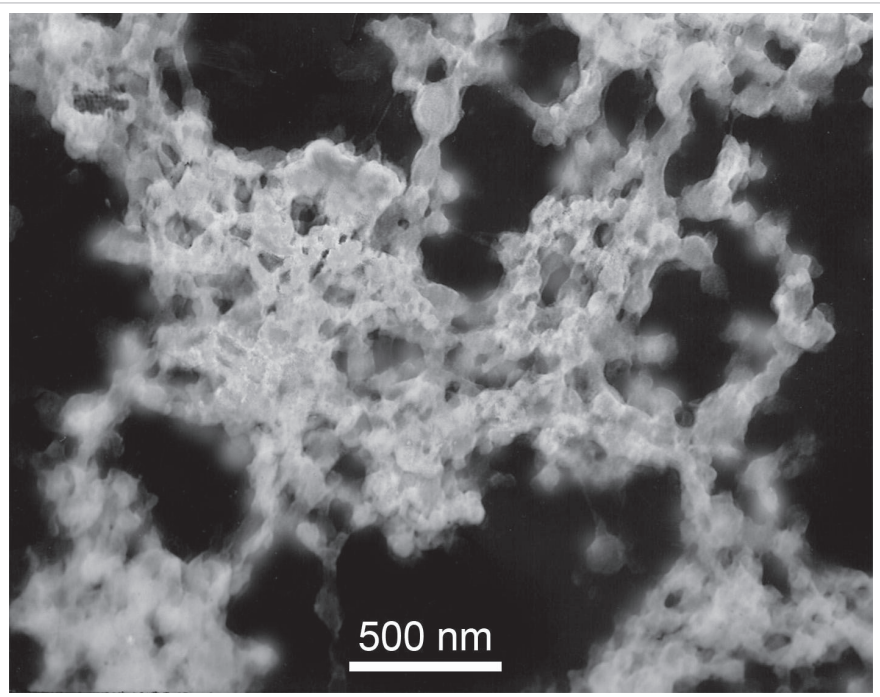

Figure 6. Nanostructure of casein-polysaccharide gel of a dairy product 
The aim of the study [25] was to determine the effect of bacterial exopolysaccharide on the milk gel formation. It was determined that the result of the interaction between casein micelles and exopolysaccharide appears in the form of an integral polysaccharide-protein network structure, in which casein micelles were interconnected by exopolysaccharide. The results obtained showed that exopolysaccharides could be used to increase the density of milk gel.

In a study [26], based on the analysis of interfacial adsorption and the microstructure of complexes observed at the air-water interface, it was demonstrated that the intramolecular electrostatic protein-polysaccharide complex, with appropriate stoichiometry, can potentially act as an effective foaming agent in the food industry.

The review [27] outlines the current understanding of the nature of the interaction of casein and pectin at the molecular level in various contexts, that is, acidified milk drinks, oil-in-water emulsions, solid particles, and other colloidal systems. Influencing factors are considered, including $\mathrm{pH}$, ionic strength, concentrations of two biopolymers, processing factors, and others. In addition, current and potential nutritional and pharmaceutical applications of some selected colloidal systems are discussed with illustrative examples. Understanding the mechanisms of casein-pectin interaction makes it possible to develop individual food systems that are of great use for increasing the stability of dairy drinks, encapsulation and protection, as well as for the controlled release of biologically active compounds.

The aim of the study [28] was to assess the ability of biopolymer complexes consisting of whey protein isolate and pectin to form and stabilize nanoemulsions with an interfacial structure. It has been shown that protein-polysaccharide complexes can be formed as a result of electrostatic interactions and can be useful for increasing the stability of nanoemulsions containing shortchain alkanes, which are subject to destabilization upon Ostwald maturation.

In [29], the influence of the acidity of the medium on the formation of stable complexes has been reviewed. It was shown that covalent and non-covalent (mainly electrostatic and hydrophobic) interactions contributed to the formation of stable complexes between caseins and polysaccharides, preventing precipitation near the isoelectric point of $\mathrm{pH} 4.5$.

Biopolymer complexes formed by proteins and polysaccharides may have some specific or innovative functionality. However, little is known about the structural characteristics and mechanisms of molecular interaction of protein-polysaccharide biopolymer complexes. Understanding these interactions is of great interest for the development of new biopolymer complexes. In [30], the structural characteristics and mechanisms of the molecular interaction of lactoferrin and $\beta$-glucan were studied. It has been shown that the binding between lactoferrin and $\beta$-glucan at $25^{\circ} \mathrm{C}$ is a spontaneous process, and electrostatic interactions, hydrogen bonds, and van der Waals interactions promote self-assembly. Self-assembly of lactoferrin- $\beta$-glucan provided the formation of physically cross-linked networks at a low concentration of $\beta$-glucan, while spherical complexes were formed at its high concentration.

The results of studies [31] have shown that the physical state of whey protein molecules (i. e., native or hydrolyzed) has a significant effect on the rate and degree of protein-polysaccharide conjugation. Low levels of hydrolysis of whey protein molecules resulted in an increase in the rate and extent of their conjugation to polysaccharides with limited associated and improved Maillard reaction products. Native and hydrolyzed solutions of the whey protein-polysaccharide conjugate had increased protein solubility and thermal stability of the solution. It is noted that the conjugation of proteins with polysaccharides represents a potential method for increasing the functionality of hydrolyzed whey proteins in food products.

The review [32] describes in detail the current trends in the creation of functional milk drinks with the addition of plantbased polysaccharides. These include drinks based on whole milk and cream, dairy by-products (whey, buttermilk), and fermented milk drinks with probiotic cultures (kefir, yogurt, etc.).

Functional drinks include health-promoting ingredients including polysaccharides of various origins in excess of the normal nutritional value of the product. The use of such polysaccharide additives as gellan gum, carboxymethyl cellulose, various types of carrageenan and pectin, as well as a number of others in dairy products, has significantly expanded the range of milk-based drinks [33, 34].

The project [35] investigated the effect of methoxylpectin, carboxymethylcellulose, and their mixtures on the stability of acidified beverages from skim and whole milk. The stability and physical properties of acid-induced skim and whole milk have been shown to be markedly transformed in the presence of these polysaccharides. The stability of the drinks improved with increasing amounts of methoxylpectin in the polysaccharide ratio, which underscores the importance of the molecular properties of this polysaccharide. The combination of these polysaccharides has been found to be better suited for stabilizing high-fat milk drinks.

Several studies [36] show that antioxidant effects are the result of a complexation reaction between phenolic compounds and milk proteins after ingestion. The main goal of the study in [37] was to determine the antioxidant and antigenotoxic effect of dairy products, milk and yoghurt after adding $2 \%$ of Korean red ginseng extract to them. This study shows that supplementing with red ginseng extract can provide enhanced antioxidant and antigenotoxic effects in dairy products and provide a new functional value-added dairy product to the market.

The work [38] provides an overview of modern knowledge about various polysaccharides of seaweed, their structural compositions, biological activity, and possible nutraceutical applications in food. It has been shown that biologically active components of seaweed polysaccharides have various useful properties, including anticoagulant, anti-inflammatory, antioxidant, anticarcinogenic and antiviral activity and can be successfully used in the development of new food products.

Protein-polysaccharide interactions were in the center of attention of scientists during research, the results of which are presented in [39]. This study aims to improve the antioxidant and hepatoprotective effects of milk proteins and whey protein hydrolyzate through non-covalent interactions with Psyllium husk plant mucilage (ispaghula) and Nabq mucilage. The chemical composition, phenolic content and antioxidant activity of milk-protein complexes were studied. The effect of the obtained complexes on liver function, hyperlipidemia and liver histopathology was also investigated. The results showed that the obtained protein-polysaccharide complexes had a significant effect on the normalization of the tested parameters.

The main purpose of the study [40] was to evaluate the physicochemical, rheological and organoleptic properties of ultrafiltered low-fat cheese, when adding various polysaccharides to it. It has been shown that the introduction of galactomannan and novagel into the composition of low-fat (8\%) cheese in a concentration $(0.1-0.5 \%)$ allows obtaining cheese with a texture and organoleptic properties very close to fatty cheeses.

\subsection{Probiotics and prebiotics}

Research work [41] reports on the prebiotic and antibiofilm potential of proteins and polysaccharides extracted in water from legumes, in particular from red beans (Phaseolus 
vulgaris L.), when they are introduced into food products. Inhibition of E. coli biofilm formation reaches $79 \%$.

The physicochemical stability of mixtures based on milk and vegetable proteins was investigated in [42]. The results obtained showed that vegetable-milk protein mixtures have rheological properties that are not a simple sum of the properties of solutions of individual proteins. Although the mechanisms underlying these effects are not fully determined in the work, it has been established that such mixtures can exhibit both synergistic and antagonistic properties that affect the physicochemical stability of food products.

The study [43] demonstrated another important effect of using a variety of polysaccharides in fermented dairy products, which significantly affect the development and existence of microorganisms. It has also been shown that different polysaccharides, when ingested, have different effects on the intestinal microbiome. The intestinal microflora respond more quickly to unstructured polysaccharides than to complex polysaccharides. The growing interest and undeniable role of prebiotics in improving the functionality of dairy products, improving their sensory characteristics and extending shelf life by suppressing the development of pathogenic microorganisms allows them to be considered as synbiotic products.

The use of the extract of whole grain quinoa flour (Weissella cibaria) in the fermented milk drink made it possible to significantly increase the viscosity of yoghurt and increase the solubility of milk protein by $54 \%$ [44], which increased its bioavailability.

Many of the polysaccharides discussed above have already been used for various purposes in the food and, in particular, the dairy industry. It is obvious that their use must be safe for humans and the environment and, therefore, an appropriate analysis of possible risks must be carried out and it is carried out. For example, the analysis carried out in [45] showed that long-term use of carrageenan in the human diet could jeopardize his health and well-being. Carrageenan over time can cause cumulative effects, manifested in the form of chronic inflammation in obesity, diabetes, and metabolic syndrome.

\subsection{Nanotechnology in manufacturing}

Despite the seeming simplicity of creating protein-polysaccharide compositions in food, in reality, all changes in food systems initially occur at the molecular and supramolecular levels. In this case, new nanoparticles, nanofibers, nanostructures, nanocapsules, etc. with specific properties can be formed. Microand macrostructures are subsequently formed from these nanoobjects, which are subsequently perceived organoleptically. Thus, the properties of food are laid down at the nanoscale, and they are manifested at the macrolevel. Therefore, the research of interactions of components in food systems at the nanoscale is currently receiving much attention $[46,47]$.

Among potential nanoparticle systems for the food industry, core-shell nanoparticles based on biopolymers are of particular interest. This interest is mainly due to their unique physical properties, including self-assembly, interfacial properties, binding capacity, as well as their high biocompatibility. In [48], various types of core-shell nanoparticles, modern methods of production, and their use as delivery systems for small molecules, proteins, and nucleic acids were considered. The main problems of their use in the food industry were also identified.

The electron microscope photograph in Figure 7 illustrates the nanostructure of the emulsion shell of a fat globule in the production of a dairy product.

The research results presented in [49] showed that nanoparticles of the ternary complex of soluble curcumin, casein, and soy polysaccharide obtained in the aqueous phase had polysac- charide surfaces, which ensured their hydrophilicity and good solubility. FTIR spectra have shown that hydrogen bonds, hydrophobic and electrostatic interactions provide the formation of ternary complex nanoparticles.

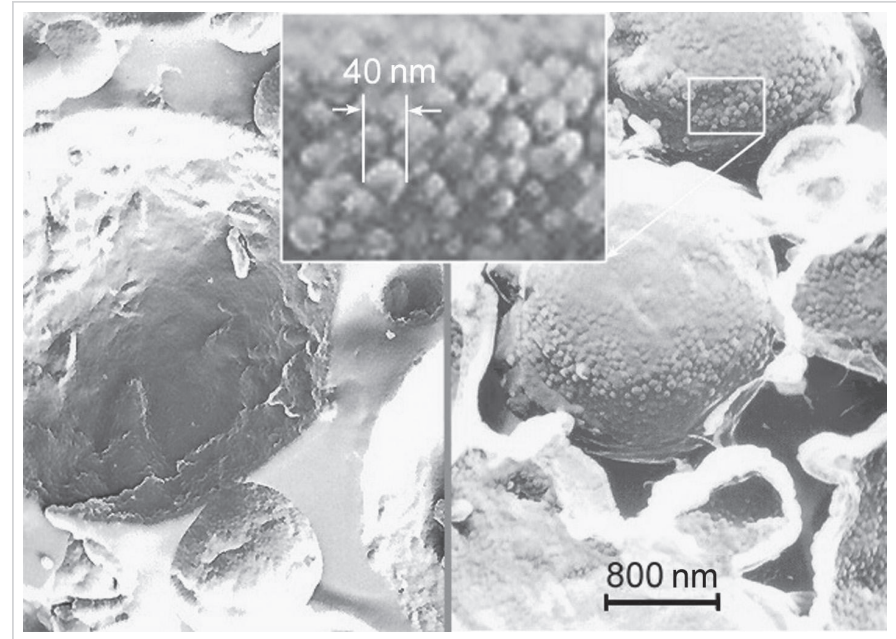

Figure 7. Nanostructure of the emulsion shell of the fat globule

In addition, nanoparticles of the ternary complex were developed and investigated in [50]. Here, a chitosan-caseinatedextran complex has been obtained through a Schiff base reaction, which has promising properties as a delivery vehicle for oral use of lipophilic bioactive substances. In particular, it is reported that the activity of encapsulated astaxanthin, which is a potential therapeutic agent for the treatment of liver fibrosis, has been significantly improved.

\subsection{Dietary fiber}

The greatest positive effect on human health can be achieved when using synbiotic substances (prebiotics) in food products, which stimulate the growth and activity of microorganisms (probiotics) and improve their adhesion to the walls of the gastrointestinal tract. These properties are common to nonhydrolyzable plant oligo- and polysaccharides such as pectin, inulin, fructooligosaccharides, xylo-oligosaccharides, and starch $[51,52]$. Dietary fibers of various origins have different physiological effects depending on the chemical composition and microstructure. This leads to the search for new sources of raw materials and a well-defined process for their use to preserve the target functional properties of the final product. Dietary fiber lowers postprandial serum glucose levels in at least three ways. Firstly, dietary fiber increases the viscosity of the juice of the small intestine and prevents the diffusion of glucose; secondly, they bind glucose and reduce the concentration of available glucose in the small intestine; and thirdly, they slow down the action of $\alpha$-amylase by encapsulating the starch and the enzyme, and can directly inhibit the enzyme.

The photograph in Figure 8 illustrates the nanostructure of dietary fiber in an innovative dairy product.

Work [53] examines current knowledge about the health effects of dietary fiber, prebiotics and dairy products. The beneficial effects of certain dietary fiber on human health - on defecation, lowering postprandial glycemic response, and maintaining normal blood cholesterol levels - are generally accepted, but other probable health benefits of dietary fiber are still debated. Although the concept of prebiotics has evolved significantly over the past two decades, the line between prebiotics and non-probiotic dietary fiber remains unclear.

Studies of the influence of processing technology of dietary fibers on their properties, the results of which are given in [54], showed that the structural modification of fibers that occurs dur- 
ing processing could lead to significant changes in fiber properties. The processing steps must be clearly defined to achieve the desired functional properties.

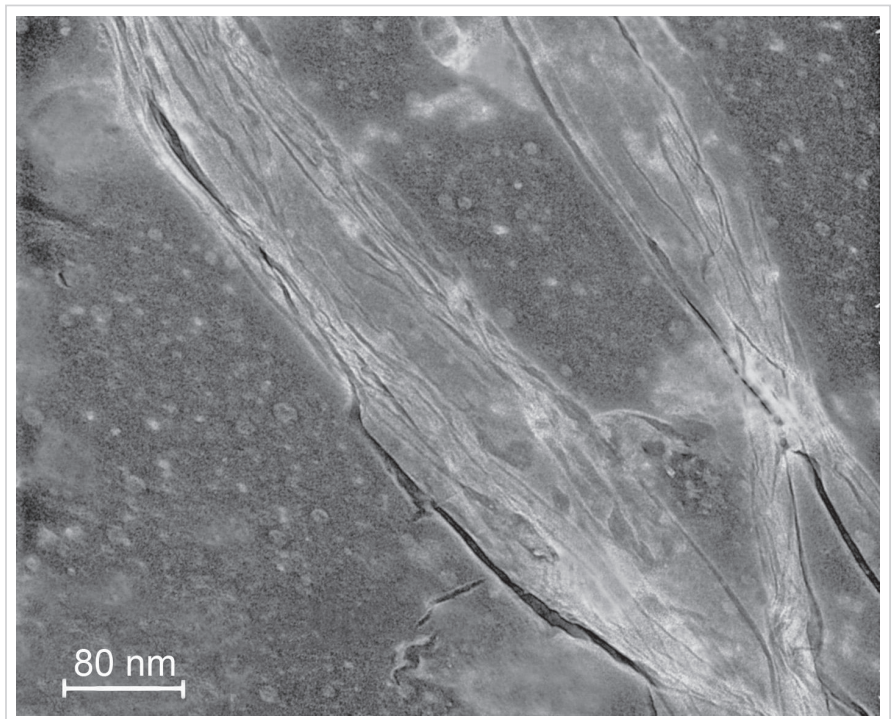

Figure 8. Nanostructure of polysaccharide dietary fiber

The effect of the addition of dietary fiber (acacia gum, inulin, and pectin) on the kinetics of milk coagulation was investigated in [55]. It has been shown that the inclusion of any fiber source significantly alters the kinetics of milk rennet coagulation. The level and significance of these changes depends on the added ingredient. The addition of acacia gum and pectin resulted in a significant reduction in duration of gel formation. The addition of acacia gum or inulin led to an increase in the elastic modulus of the coagulum. While the addition of pectin initially reduced the coagulation time, higher levels of the ingredient resulted in its increase.

The innovative development of food products, including milk proteins and dietary fiber, increases the bioavailability of individual components to meet consumer needs, while improving their sensory properties. A review [56] of significant results in the developing field of dairy protein-ligand interactions may help in planning experiments to create the required products. It is noted that at a fundamental level, it is necessary to understand the kinetics of molecular transport of biologically active compounds, including after heat treatment, from compositions based on protein and dietary fiber in nutraceutical-type products.

Along with the use of dietary fiber in dairy products, attempts to develop and use synthetic dietary fibers continue. For their synthesis, both proteins of various (dairy) origin and polysaccharides are used. Thus, in [57], an electromechanical (electrospinning) method for producing dietary fiber from maltodextrin with whey protein isolate and soy protein isolate is considered. The study demonstrated the successful electrospinning of dietary fibers from aqueous solutions and the dependence of fiber properties on their composition.

\subsection{Technological applications}

The results of studies of the interaction of casein micelles with $\kappa$-carrageenan and $\lambda$-carrageenan, carried out using scanning electron microscopy [58], showed that the ability of $\kappa$-carrageenan to form gel, in contrast to $\lambda$-carrageenan, is explained by the ability of $\kappa$-carrageenan to form larger aggregates at a similar concentration of carrageenan. This is achieved by the formation of $\kappa$-carrageenan strands, to which casein micelles are attached, which is not observed for $\lambda$-carrageenan. It is also suggested that part of the product structure arises from the unfolding of casein micelles upon dehydration.
The effect of $\kappa$-carrageenan on acid-induced gelation of whey proteins was studied in [59], where the effect of adding $\kappa$-carrageenan on the relationship between the total charge density of proteins and $\mathrm{pH}$ was determined and it was shown that an increase in the gelation temperature leads to an increase in its elastic modulus.

Four polysaccharides of plant origin - okra polysaccharide, apple pectin, sodium alginate and konjac glucomannan - were studied in yoghurt to study their effect on gelation characteristics [60]. The results showed that okra polysaccharide, konjac glucomannan and apple pectin increased the water holding capacity, density and elasticity of yoghurt, while sodium alginate showed opposite effects. Research has also shown that the addition of okra polysaccharide and apple pectin reduces the porous structure of the gel and promotes the formation of larger protein clusters, ultimately resulting in a more compact protein network.

The work [61] was devoted to the assessment of the microstructural, rheological, and textural state of aqueous mixtures of sodium caseinate and gum container and their acid gels. Acid gels with different microstructure and texture were obtained, depending on the concentration ratio of both biopolymers, either a continuous network of a protein gel or a water-in-water emulsion was observed.

Rheological and microscopic studies of the stabilizing effect of salecan on the structure of yoghurt were carried out in [62]. Molecules of salecan, a linear, negatively charged polysaccharide representing $(1 \rightarrow 3)$ - $\beta$-D-glucan, formed an additional string structure in yogurt that anchors casein micelles. The new structure provided yoghurt with increased stability, improved rheological

The effect of pullulan on the physicochemical properties of yoghurt was investigated in [63]. It was determined that yoghurt with $1 \%$ of pullulan has a weakened milk gel structure, with a reduced initial viscosity and increased syneresis compared to the control. The addition of $2 \%$ of pullulan significantly improves product stability by increasing gel strength, higher viscosity, and reduced syneresis. This study demonstrated that the physicochemical properties of yoghurt are largely determined by the concentration of pullulan in yoghurt.

In an experimental study [64], a soluble fraction of polysaccharides was isolated from the fungal fruit of Pleurotus ostreatus mushrooms (oyster mushroom), which was used to stabilize a casein-gluconate matrix of kefir with a low lactose content. Research has shown that the soluble fraction of polysaccharides added to milk before fermentation affects the texture of the finished kefir, organoleptically improving its texture.

The aim of the study in [65] was to evaluate the properties of yoghurt powder obtained by drying in a drying cabinet; carrageenan was added to the yoghurt at the initial stage as a stabilizer. It was shown that the optimal concentration of carrageenan was $2 \%$, while the resulting yoghurt powder had the highest bulk density and the best granulometric texture. The water activity in the resulting product was rather low, which ensured a long shelf life. Better recovery of the yoghurt was achieved using warm water, resulting in a stable product with no visible phase separation.

\subsection{Whey protein binding}

The study of the mechanism of interaction between whey proteins and polysaccharides is the subject of work [66]. The structure-function relationship was determined for mixtures of basil gum and whey protein isolate at the beginning of the formation of a soluble complex, the formation of the most soluble complex and the prevailing thermodynamic incompatibility. Regardless of the ratio of the components in the mixture, all dispersions showed the maximum interaction at $\mathrm{pH}=5.0$, the beginning of the formation of a soluble complex near $\mathrm{pH}=6.0$, and the behavior of the interaction of thermodynamic incompatibility at $\mathrm{pH}=7.0$. Cole-Cole 
diagrams based on dynamic rheometry confirmed the Gibbs free energy change of mixtures based on intrinsic viscosity data. The results obtained are important for creating new structures from mixtures of proteins and polysaccharides.

The effect of various extracts of chia and flax seed mucilage on the kinetics of acid gelation of whey proteins was investigated in [67]. Based on a model adapted to the Flory-Stockmeier theory, it has been demonstrated that the presence of mucilage extracts from plant seeds inhibits the cross-linking ability of whey proteins, which leads to the formation of short protein crosslinks and therefore reduces gel hardness. However, it was found that the rate of formation of elastically active structural networks increases with a certain content of mucus extracts, which indicates a synergistic effect of gel structuring. The mucilage type and the protein to polysaccharide ratio mainly determine the structuring and stabilizing properties of seed mucilage extracts in cold-set whey protein gels.

In [68], the results of studies of the surface and gel rheology of whey protein isolate under the influence of hydrophobization, thermal denaturation, and the addition of erythritol were presented. Hydrophobization shortened the linear viscoelastic area and decreased the surface tension modulus. The addition of erythritol to the hydrophobized protein caused a further decrease in the surface tension modulus. Hydrophobization of whey proteins followed by the addition of erythritol to the hydrophobized protein dispersion made it possible to form water-water (W/W) emulsions of proteins and alginate. Modification of whey proteins through hydrophobization can alter the cold-set gelation process and the rheology of the whey protein isolate gel. The cold-set gelling process occurs in two stages. Whey proteins are initially denatured by heat under non-gelation conditions (i. e., under low ionic strength, low protein content, and at $\mathrm{pH}$ values far from the protein's isoelectric point, $\mathrm{pI}$ ), resulting in the formation of soluble whey protein aggregates. The protein dispersion can then be gelled at ambient temperature by adding salt and / or adjusting the $\mathrm{pH}$ in the $\mathrm{pI}$ direction. The rheology of such gels is determined by the interaction of aggregating protein particles, which strongly depends on the chemical composition of the aggregates [69].

The production of dairy products using high pressure is one of the new technologies for non-thermal milk processing, which makes it possible to obtain mixed protein-polysaccharide gels that can encapsulate and store thermosensitive biologically active compounds. The study [70] studied the properties of mixed gels of $\beta$-lactoglobulin and $\kappa$-carrageenan, obtained under pressure (0.1-600 MPa) for 30 minutes at $25^{\circ} \mathrm{C}$. The results showed that the pressure required to form these mixed gels was at least 400 $\mathrm{MPa}$. Exposure to high pressure induced hydrophobic interactions between the components of the mixed gel at all $\mathrm{pH}$ values, and the gel structure was more compact and uniform at higher pressures.

The work [71] presents the results of systematic studies of the relationship between the electrostatic interaction of whey protein isolate / sodium alginate and the viscosity of the foam, the characteristics of interfacial adsorption, and the microstructure of the complexes observed at the air-water interface. It has been demonstrated that the electrostatic protein / polysaccharide complex can potentially act as an effective foaming agent in the food industry.

The aim of the research was [72] to study the effect of exopolysaccharides produced in situ by bacteria Leuconostoc pseudomesenteroides and Weissella confusa on the properties of the protein concentrate of common beans. A clear improvement in rheological and textural properties was shown, which was observed in pastes with the addition of sucrose after fermentation.

\subsection{Packaging}

Proteins and polysaccharides, as well as their compositions, can be used to not only create new dairy products or improve their properties, but also to increase the efficiency of technological processes for their production and storage. For example, the review [73] considers the creation of packaging materials for food products, their mechanical and thermal stability, biodegradability, non-toxicity, and antibacterial activity when using bionanocomposites of various proteins and polysaccharides. It is noted that along with the positive properties of polysaccharides, such as chitosan, carboxymethylcellulose, starch and cellophane, in relation to packaging materials, polysaccharides have some deficiencies, for example, poor mechanical properties and low water resistance. It has been shown that these deficiencies can be eliminated in the development of bionanocomposites based on polysaccharides. An article [74] is also devoted to a review of current advances in research and development of protein-based bionanocomposites for use in food packaging. The interest in protein-based biocomposites is due to their stability, renewability, biodegradability, and low carbon footprint. The inherent deficiencies of protein-based materials for food packaging are their low mechanical strength, poor thermal, barrier, and low physicochemical properties. Bionanocomposites based on the combined basis of proteins and polysaccharides provide an opportunity to overcome these problems and can displace non-biodegradable plastic for food packaging made from petroleum resources.

In [75], it is noted that replacing existing plastics with modern packaging materials obtained from non-renewable sources requires the creation of new environmentally friendly biopolymers. Natural products such as protein-containing waste from dairy plants have significant potential for bioplastics. Rich in casein and whey proteins, material collected from dairy wastewater using a flotation procedure is self-associating and has the potential to form bioplastics, but produces brittle films. The use of additional biopolymers such as polysaccharides to form composites with these proteins has the potential to improve the physical properties of such films.

\subsection{Manufacturing applications}

Industrial wastewater from dairy plants contains a variety of valuable residual materials, including lactose, milk fat, phospholipids, and milk proteins. It is clear that there are economic, environmental and social benefits to the efficient recovery of these materials from dairy wastewater. Since the volume of this wastewater discharge is enormous and the concentration of materials is low, isoelectric precipitation, salting out and ion exchange adsorption are not cost effective. Work [76] demonstrates the promise of using the flotation method for the extraction of casein from wastewater generated during milk processing. It has been shown that the best results are obtained by using xanthan gum as a foam stabilizer based on the association between a protein and a polysaccharide. Electrostatic interactions between protein and polysaccharide, which is significantly dependent on $\mathrm{pH}$, provide a close relationship between them and have a noticeable effect on surface tension, foaming, foam stability, zeta potential and average particle size of the dispersion. The level of extraction of casein from dairy wastewater using the flotation process reached 86 percent in the experiment.

\section{Conclusion}

The interaction of milk proteins with polysaccharides of various origins and possessing a wide variety of properties, as well as the use of non-dairy proteins in the production of dairy products, has recently attracted the attention of researchers in many countries of the world. The nature of protein-polysaccharide interactions, depending on the proteins and polysaccharides used in various combinations and the conditions of their interactions can be completely different. Therefore, despite the different 
goals pursued by researchers, ultimately all research is aimed at finding basic patterns in these interactions.

Knowledge of the basic patterns of protein-polysaccharide interactions makes it possible to simplify the achievement of the following main goals in food production:

$\square$ obtaining balanced food products for functional purposes;

$\square$ involvement in the production of new food raw materials;

$\square$ improving the quality of products;

$\square$ increasing the shelf life of products;

$\square$ increasing the efficiency of production processes; $\square$ reduction of production waste;

creation of biodegradable non-toxic packaging materials.

Modern studies of protein-polysaccharide interactions are based on the use of high-tech analytical equipment, such as electron and confocal microscopy, spectrometry of various types, etc. As these studies have shown, the physicochemical and, accordingly, organoleptic properties of food products are laid down at the nanoscale, and are already manifested at the macro level at the consumer.

\section{REFERENCES}

1. Iriondo-DeHond, M., Miguel, E., del Castillo, M.D. (2018). Food Byproducts as Sustainable Ingredients for Innovative and Healthy Dairy Foods. Nutrients, 10, 1358. http://doi.org/10.3390/nu10101358

2. Yemenicioğlu, A., Farris, S., Turkyilmaz, M., Gulec, S. (2020). A review of current and future food applications of natural hydrocolloids. International Journal of Food Science \& Technology, 55(4), 1389-1406. https://doi. org/10.1111/ijfs.14363

3. Cao, Y., Mezzenga, R. (2020). Design principles of food gels. Nature Food, 1, 106-118. https://doi.org/10.1038/s43016-019-0009-x

4. Bealer, E.J., Onissema-Karimu, S., Rivera-Galletti, A., Francis, M., Wilkowski, J., Salas-de la Cruz, D., Hu, X. (2020). Protein-Polysaccharide Composite Materials: Fabrication and Applications. Polymers, 12(2), 464. https://doi.org/10.3390/polym12020464

5. Dalgleish, D.G., Spagnuolo, P.A., Goff, H.D. (2004). A possible structure of the casein micelle based on high-resolution field-emission scanning electron microscopy. International Dairy Journal, 14(12), 1025-1031. https://doi.org/10.1016/j.idairyj.2004.04.008

6. Holt, C., Horne, D.S. (1996). The hairy casein micelle: evolution of the concept and its implications for dairy technology. Netherlands Milk Dairy Journal, 50, 85-111.

7. Holt, C., Carver, J.A., Ecroyd, H., Thorn, D.C. (2013). Invited review: Caseins and the casein micelle: Their biological functions, structures, and behavior in foods. Journal of Dairy Science, 96(10), 6127-6146. https://doi. org/10.3168/jds.2013-6831

8. Whey Proteins: From Milk to Medicine. (2018). Ed. by: Deeth, H.C., Bansal, N. Elsevier, Academic Press, UK. -746 p. ISBN: 978-0-12-812124-5

9. Milk Proteins: From Expression to Food, (2020). Third. ed., Ed. by: Boland, M., Singh, H. Elsevier, Academic Press, UK. 764 p. ISBN: 978-0-12815251-5. https://doi.org/10.1016/B978-0-12-815251-5.09989-8

10. Balandrán-Quintana, R.R., Mendoza-Wilson, A.M., Montfort, G.R.-C., Huerta-Ocampo, J.Á. (2019). Plant-Based Proteins. In book: Proteins: Sustainable Source, Processing and Applications, ed. by Galanakis, C. M. Academic Press, 358 p. ISBN:9780128166956. https://doi.org/10.1016/B9780-12-816695-6.00004-0

11. Lin, D., Lu, W., Kelly, A.L., Zhang, L., Zheng, B., Miao, S. (2017). Interactions of vegetable proteins with other polymers: Structure-function relationships and applications in the food industry. Trends in Food Science \& Technology, 68, 130-144. https://doi.org/10.1016/i.tifs.2017.08.006

12. Razavi, S.M.A. (2019). Introduction to Emerging Natural Hydrocolloids. In book: Emerging Natural Hydrocolloids: Rheology and Functions,. Ed. by Razavi, S.M.A. First Edition. John Wiley \& Sons Ltd, 672 p. ISBN: 978-1119-41866-5

13. Yi, Y., Xu, W., Wang, H.-X., Huang, F., Wang, L.-M. (2020). Natural polysaccharides experience physiochemical and functional changes during preparation: A review. Carbohydrate Polymers, 234(15), 115896. https://doi.org/10.1016/i.carbpol.2020.115896

14. Kobayashi, S. (2007). New developments of polysaccharide synthesis via enzymatic polymerization. Proceedings of the Japan Academy, Ser. B, Physical and Biological Sciences, 83(8), 215-247. https://doi.org/10.2183 / pjab / 83.215

15. Food polysaccharides and their applications. (2006). ed. by Stephen, A.M., Phillips, G.O., Williams, P.A. - 2nd ed. CRC Press, 712 p. ISBN08247-5922-2

16. Soukoulis, C., Gaiani, C., Hoffmann, L. (2018). Plant seed mucilage as emerging biopolymer in food industry applications, Current Opinion in Food Science, 22, 28-42. https://doi.org/10.1016/j.cofs.2018.01.004

17. Ramalingam, C., Priya, J., Mundra, S. (2014). Applications of Microbial Polysaccharides in Food Industry. International Journal of Pharmaceutical Sciences Review and Research, 27(1), 58, 322-324.

18. Gentès, M.-C., St-Gelais, D., Turgeon, S.L. (2011). Gel formation and rheological properties of fermented milk with in situ exopolysaccharide production by lactic acid bacteria. Dairy Science \& Technology, 91(5), 645661. https://doi.org/10.1007/s13594-011-0039-0

19. Biopolymers for Food Design. (2018). Ed. by: Grumezesku, A.M., Holban, A. M. Academic Press, Elsevier Inc. 536 p. ISBN: 978-0-12-811449-0. https://doi.org/10.1016/C2016-0-00686-1

20. Food polysaccharides and their applications. (2006). Ed. by Stephen, A. M., Phillips, G.O., Williams, P. A. - 2nd ed., CRC Press, Taylor \& Francis Group, 712 p. ISBN: 0-8247-5922-2
21. Sulieman, A.M.E-H. (2018). Gum Arabic as Thickener and Stabilizing Agents in Dairy Products, p 142-165. In book: Gum Arabic: Structure, Properties, Application and Economics. Ed. by: Mariod, A. A. Elsevier Inc. 342 p. https://doi.org//10.1016/B978-0-12-812002-6.00013-0

22. Goh, K.K.T., Teo, A., Sarkar, A., Singh, H. (2019). Milk protein-polysaccharide interactions. In book: Milk Proteins: From Expression to Food. Eds. by Boland, $\mathrm{M}$ and Singh, H. Academic Press, London, UK, 536 p. ISBN978-012-815251-5. https://doi.org/10.1016/B978-0-12-815251-5.00013-X

23. Gentile, L. (2020). Protein-polysaccharide interactions and aggregates in food formulations. Current Opinion in Colloid \& Interface Science, 48 18-27. https://doi.org/10.1016/i.cocis.2020.03.002

24. Manab, A. (2017). Casein polysaccaharides interaction - A Review. Inter national Journal of ChemTech Research, 10(5), 01-09.

25. Malaka, R., Ohashi, T., Baco, S. (2013). Effect of Bacteria Exopolysaccharide on Milk Gel Formation. Open Journal of Forestry, 3(4B), 10-12. https://doi.org//10.4236/ojf.2013.34B004

26. Xu, Y., Yang, N., Yang, J., Hu, J., Zhang, K., Nishinari, K., Phillips, G.O. Fang, Y. (2020). Protein/polysaccharide intramolecular electrostatic complex as superior food-grade foaming agent. Food Hydrocolloids, 101, 105474._https://doi.org/10.1016/j.foodhyd.2019.105474

27. Wusigale, Liang, L., Luo, Y. (2020). Casein and pectin: Structures, interactions, and applications. Trends in Food Science \& Technology, 97, 391-403. https://doi.org/10.1016/i.tifs.2020.01.027

28. Artiga Artigas, M., Reichert, C., Salvia Trujillo, L., Zeeb, B., Martín Belloso, O., Weiss, J. (2020). Protein/Polysaccharide Complexes to Stabilize Decane-in-Water Nanoemulsions. Food Biophysics, In press. https://doi. org/10.1007/s11483-019-09622-x

29. Li, N., Zhong, Q. (2020). Casein core-polysaccharide shell nanocomplexes stable at $\mathrm{pH} 4.5$ enabled by chelating and complexation properties of dextran sulfate. Food Hydrocolloids, 103, 105723. https://doi.org/10.1016/i. foodhyd.2020.105723

30. Yang, W.,_Deng, C., Xu, L., Jin, W., Zeng, J., Li, B., Gao, Y. (2020). Protein neutral polysaccharide nano- and micro-biopolymer complexes fabricated by lactoferrin and oat $\beta$-glucan: Structural characteristics and molecular interaction mechanisms. Food Research International, 132, 109111. https://doi.org/10.1016/j.foodres.2020.109111

31. Mulcahy, E.M. (2017). Preparation, characterisation and functional applications of whey protein-carbohydrate conjugates as food ingredients. PhD Thesis, University College Cork.

32. Sukhikh, S., Astakhova, L., Golubcova, Y., Lukin, A., Prosekova, E., Kos tina, N., Rasshchepkin, A. (2019). Functional dairy products enriched with plant ingredients. Foods and Raw materials, 7(2), 428-438. http:/doi. org/10.21603/2308-4057-2019-2-428-438

33. Walsh, M.C., Gunn, C. (2020). Non-dairy milk substitutes: Are they of adequate nutritional composition? In book: Milk and Dairy Foods, Thei Functionality in Human Health and Disease, ed. by Givens, I. Elsevier Inc., 440 p. https://doi.org/10.1016/B978-0-12-815603-2.00013-9

34. Kabanov, V.L., Novinyuk, L.V. (2020). Chitosan application in food technology: F review of recent advances. Food systems. 3(1),10-15. https://doi. org/10.21323/2618-9771-2020-3-1-10-15

35. Yuliarti, O., Mei, K.H., Ting, Z.K.X., Yi, K.Y. (2019). Influence of combination carboxymethylcellulose and pectin on the stability of acidified milk drinks. Food Hydrocolloids, 89, 216-223. https://doi.org/10.1016/j.foodhyd.2018.10.040

36. Abd El-Maksoud, A.A., Abd El-Ghany, I.H., El-Beltagi, H.S., Anankanbil S., Banerjee, C., Petersen, S.V., Perez, B., Guo, Z. (2018). Adding functionality to milk-based protein: Preparation, and physico-chemical characterization of beta-lactoglobulin-phenolic conjugates. Food Chemistry, 241, 281-289. https://doi.org/10.1016/j.foodchem.2017.08.101

37. Park, H., Lee, M., Kim, K.-T., Park, E., Paik, H.-D. (2018). Antioxidant and antigenotoxic effect of dairy products supplemented with red ginseng extract. Journal of Dairy Science. 101(10), 8702-8710. https://doi org/10.3168/jds.2018-14690

38. Tanna, B., and Mishra, A. (2019). Nutraceutical Potential of Seaweed Polysaccharides: Structure, Bioactivity, Safety, and Toxicity. Comprehensive Reviews in Food Science and Food Safety, 18(3), 817-831. https://doi. org/10.1111/1541-4337.12441

39. Abd El-Maksoud, A.A., Korany, R.M.S., Abd El-Ghany, I.H., El-Beltagi, H.S., de Gouveia G. M.A.F. (2020). Dietary solutions to dyslipidemia: Milk 
protein-polysaccharide conjugates as liver biochemical enhancers. Journal of Food Biochemistry, 44(3), https://doi.org/10.1111/jfbc.13142

40. Sharafi, S., Nateghi, L., Eyvazzade, O., Ebrahimi, M.T.A. (2020). The physicochemical, texture hardness and sensorial properties of ultrafiltrated low-fat cheese containing galactomannan and novagel gum. Acta Sci.Pol. Technol. Aliment. 19(1), 83-100. https://doi.org/10.17306/J.AFS.2020.0685

41. Jayamanohar, I., Devi, P.B., Kavitake, D., Priyadarisini, V.B., Shetty, P.H. (2019). Prebiotic potential of water extractable polysaccharide from red kidney bean (Phaseolus vulgaris L.). LWT - Food Science and Technology, 101, 703-710. https://doi.org/10.1016/j.lwt.2018.11.089

42. Ho, K.K.H.Y., Schroën, K., San Martín-González, M.F., Berton-Carabin, C.C. (2018). Synergistic and antagonistic effects of plant and dairy protein blends on the physicochemical stability of lycopene-loaded emulsions. Food Hydrocolloids, 81, 180-190. https://doi.org/10.1016/j.foodhyd.2018.02.033

43. Fazilah, N.F., Ariff, A.B., Khayat, M.E., Rios-Solis, L., Halim, M. (2018). Influence of probiotics, prebiotics, synbiotics and bioactive phytochemicals on the formulation of functional yogurt. Journal of Functional Foods, 48 , 387-399. https://doi.org/10.1016/j.jff.2018.07.039

44. Zannini, E., Jeske, S., Lynch, K., Arendt, E.K. (2018). Development of novel quinoa-based yoghurt fermented with dextran producer Weissella cibaria MG1. International Journal of Food Microbiology, 268, 19-26. https://doi. org/10.1016/j.ijfoodmicro.2018.01.001

45. David, S., Levi, C.S., Fahoum, L., Ungar, Y., Meyron-Holtz, E. G., Shpigelman, A., Lesmes, U. (2018). Revisiting the carrageenan controversy: do we really understand the digestive fate and safety of carrageenan in our foods? Food \& Function, 9, 1344-1352. https://doi.org/10.1039/C7FO01721A.

46. Smykov, I.T. (2020). Nanotechnology in dairy industry. In book ESLI: Handbook of Nanotechnology, ed. by Hussain, C.M., Wiley - Scrivener, 468 p.

47. Characterization of Nanoencapsulated Food Ingredients, Volume 4, Nanoencapsulation in the Food Industry. (2020), ed. by S. M. Jafari. Academic Press, Elsevier, 696 p. ISBN: 978-0-12-815667-4, https://doi. org/10.1016/C2017-0-03547-4

48. Zhang, Y., Wang, L. (2020). Core-shell biopolymer nanoparticles. In book: Biopolymer-Based Formulations: Biomedical and Food Applications, eds. by: Pal, K., Banerjee, I., Sarkar, P., Kim, D., Deng, W.-P., Dubey, N.K., Majumder, K. Elsevier Science, 969 p. ISBN: 9780128168981 . https://doi. org/10.1016/B978-0-12-816897-4.00010-2

49. Xu, G., Li, L., Bao, X., Yao, P. (2020). Curcumin, casein and soy polysaccharide ternary complex nanoparticles for enhanced dispersibility, stability and oral bioavailability of curcumin. Food Bioscience, 35, 100569, in Press https://doi.org/10.1016/j.fbio.2020.100569

50. Hu, Q., Hu, S., Fleming, E., Lee, J.-Y., Luo, Y. (2020). Chitosan-caseinatedextran ternary complex nanoparticles for potential oral delivery of astaxanthin with significantly improved bioactivity. International Journal of Biological Macromolecules, 151, 747-756. https://doi.org/10.1016/j. ijbiomac.2020.02.170

51. Anderson, J. W., Baird, P., Davis Jr, R.H., Ferreri, S., Knudtson, M., Koraym, A., Waters, V., Williams, C. L. (2009). Health benefits of dietary fiber. Nutrition Reviews. 67(4), 188-205. https://doi.org/10.1111/j.1753-4887.2009.00189

52. Reynolds, A., Mann, J., Cummings, J., Winter, N., Mete, E., Morenga, L.T. (2019). Carbohydrate quality and human health: a series of systematic reviews and meta-analyses. The Lancet, 393, 434-445. https://doi. org/10.1016/S0140-6736(18)31809-9

53. Pop, O.L., L.-C., Salanță, L.-C., Pop, C.R., Coldea, T., Socaci, S.A., Suharoschi, R., Vodnar, D. C. (2019). Prebiotics and Dairy Applications. In book: Dietary Fiber: Properties, Recovery, and Applications, ed. by Galanakis, C.M., Elsevier Inc., 364 p. ISBN: 978-0-12-816495-2. https://doi. org/10.1016/B978-0-12-816495-2.00008-3

54. Chiewchan, N. (2018). Microstructure, constituents, and their relationship with quality and functionality of dietary fibers. In book: Food Microstructure and Its Relationship with Quality and Stability, ed. by Devahastin, S. Elsevier Ltd., Woodhead Publishing, Thailand. 300 p. ISBN: 978-0-08100764-8. https://doi.org//10.1016/B978-0-08-100764-8.00010-1

55. Fagan, C.C., O’Donnell, C.P., Cullen, P.J., Brennan, C.S. (2006). The effect of dietary fibre inclusion on milk coagulation kinetics. Journal of Food Engineering, 77, 261-268. https://doi.org/10.1016/j.jfoodeng.2005.06.030

56. Condict, L., Paramita V. D., Kasapis, S. (2019). Dairy protein-ligand interactions upon thermal processing and targeted delivery for the design of functional foods, Current Opinion in Food Science, 27, 8-17. https://doi. org/10.1016/j.cofs.2019.03.007

57. Kutzli, I., Gibis, M., Baier, S.K., Weiss, J. (2019). Electrospinning of whey and soy protein mixed with maltodextrin - Influence of protein type and ratio on the production and morphology of fibers, Food Hydrocolloids, 93, 206-214. https://doi.org/10.1016/j.foodhyd.2019.02.028

58. Martin, A.H., Goff, H.D., Smith, A., Dalgleish, D.G. (2006). Immobilization of casein micelles for probing their structure and interactions with poly- saccharides using scanning electron microscopy (SEM). Food Hydrocolloids, 20, 817-824. https://doi.org/10.1016/j.foodhyd.2005.08.004

59. Liu, D., Zhou, P., Nicolai, T. (2020). Effect of Kappa carrageenan on acidinduced gelation of whey protein aggregates. Part I: Potentiometric titration, rheology and turbidity. Food Hydrocolloids, 102, 105589. https://doi. org/10.1016/j.foodhyd.2019.105589

60. Xu, K., Guo, M., Du, J., Zhang, Z. (2019). Okra polysaccharide: Effect on the texture and microstructure of set yoghurt as a new natural stabilizer. International Journal of Biological Macromolecules, 133, 117-126. https://doi.org/10.1016/j.ijbiomac.2019.04.035

61. Hidalgo, Ma.E., Ingrassa, R., Nielsen, N.S., Porfiri, Ma.C., Tapia-Maruri, D., Risso, P.H. (2020). Tara gum-bovine sodium caseinate acid gels: Stabilisation of W/W emulsions. International Journal of Dairy Technology, 73(3), 521-531. https://doi.org/10.1111/1471-0307.12693

62. Fu, R., Li, J., Zhang, T., Zhu, T., Cheng, R., Wang, S., Zhang, J. (2018). Salecan stabilizes the microstructure and improves the rheological performance of yogurt, Food Hydrocolloids, 81, 474-480. https://doi. org/10.1016/i.foodhyd.2018.03.034

63. Kycia, K., Chlebowska-Smigiel, A., Gniewosz, M., Sokol, E. (2017). Effect of pullulan on the physicochemical properties of yoghurt. International Journal of Dairy Technology, 71(1), 64-70. https://doi.org/10.1111/14710307.12401

64. Cais-Sokolinska, D., Stachowiak, B., Kaczynski, Ł.K., Bierzunska, P., Gorna, B. (2018). The stability of the casein-gluconate matrix in reducedlactose kefir with soluble fraction polysaccharides containing b-glucan from Pleurotus ostreatus. International Journal of Dairy Technology, 71(1), 122-130. https://doi.org/10.1111/1471-0307.12429

65. Pratama, Y., Abduh, S.B.M., Legowo, A.M., Pramono, Y.B., Albaarri, A.N (2018). Optimum carrageenan concentration improved the physical properties of cabinet-dried yoghurt powder IOP Conf. Ser.: Earth Environ. Sci. 102012023 IOP Conference Series: Earth and Environmental Science.

66. Behrouzain, F., Razavi, S.M.A., Joyner, H. (2020). Mechanisms of whey protein isolate interaction with basil seed gum: Influence of $\mathrm{pH}$ and protein-polysaccharide ratio. Carbohydrate Polymers, 232, 115775. https://doi.org/10.1016/j.carbpol.2019.115775

67. Soukoulis, C., Cambier, Sé., Serchi, T., Tsevdou, M., Gaiani, C., Ferrer, P. Taoukis, P.S., Hoffmann, L. (2019). Rheological and structural characterisation of whey protein acid gels co-structured with chia (Salvia hispanica L.) or flax seed (Linum usitatissimum L.) mucilage, Food Hydrocolloids, 89 , 542-553. https://doi.org/10.1016/j.foodhyd.2018.11.002

68. Madadlou, A., Famelart, M. - H., Pezennec, S., Rousseau, F., Floury, J., Dupont, D. (2020). Interfacial and (emulsion) gel rheology of hydrophobised whey proteins. International Dairy Journal, 100, 104556. https://doi org/10.1016/j.idairyj.2019.104556

69. Alting, A.C., Hamer, R.J., De Kruif, C.G., Visschers, R.W. (2003). Cold-Set Globular Protein Gels: Interactions, Structure and Rheology as a Function of Protein Concentration. Journal of Agricultural and Food Chemistry, 51(10), 3150-3156. https://doi.org/10.1021/jf0209342

70. Li, X., He, X., Mao, L., Gao, Y., Yuan, F. (2020). Modification of the structural and rheological properties of $\beta$-lactoglobulin $/ \kappa$-carrageenan mixed gels induced by high pressure processing. Journal of Food Engineering, 274, 109851. https://doi.org/10.1016/j.jfoodeng.2019.109851

71. Xu, Y., Yang, N., Yang, J., Hu, J., Zhang, K., Nishinari, K., Phillips, G.O., Fang, Y. (2020) Protein/polysaccharide intramolecular electrostatic complex as superior food-grade foaming agent. Food Hydrocolloids, 101, 105474. https://doi.org/10.1016/i.foodhyd.2019.105474

72. Xu, Y., Coda, R., Holopainen-Mantila, U., Laitila, A., Katina, K., Tenkanen, M. (2019). Impact of in situ produced exopolysaccharides on rheol ogy and texture of fava bean protein concentrate. Food Research International, 115, 191-199. https://doi.org/10.1016/j.foodres.2018.08.054

73. Youssef, A.M., El-Sayed, S.M. (2018). Bionanocomposites materials for food packaging applications: Concepts and future outlook. Carbohydrate Polymers, 193, 19-27. doi: 10.1016/j.carbpol.2018.03.088

74. Zubair, M., Ullah, A. (2020). Recent advances in protein derived bionanocomposites for food packaging applications, Critical Reviews in Food Science and Nutrition, 60(3), 406-434. https://doi.org/10.1080 10408398.2018.1534800

75. Ryder, K., Ali, M.A., Billakanti, J., Carne, A. (2020). Evaluation of Dairy Coproduct Containing Composite Solutions for the Formation of Bioplastic Films. Journal of Polymer Environ, 28, 725-736. https://doi.org/10.1007/ s10924-019-01635-4

76. Wu, Z., Yin, H., Liu, W., Huang, D., Hu, N., Yang, C., Zhao, X. (2020). Xanthan gum assisted foam fractionation for the recovery of casein from the dairy wastewater. Preparative Biochemistry \& Biotechnology, 50(1), 37-46. https://doi.org/10.1080/10826068.2019.1658119

\section{AUTHOR INFORMATION}

Igor T. Smykov - doctor of technical sciences, chief research scientist, All-Russian Scientific Research Institute of Butter- and Cheesemaking - Branch of V. M. Gorbatov Federal Research Center for Food Systems of RAS. 152613, Yaroslavl Region, Uglich, Krasnoarmeysky Boulevard, 19. Tel.: + 7-485-329-81-21. E-mail: i_smykov@mail.ru 